\title{
Authority of Discretion of Regional Heads in Government Implementation to Make Public Welfare
}

\author{
Oloan Paniaran Nababan \\ Student at Doctoral Program of Law, Borobudur University, Jakarta Indonesia \\ Azis Budianto \\ Borobudur University, Faculty of Law, Jakarta Indonesia
}

\begin{abstract}
Article 1 paragraph (3) of the 1945 Constitution of the Republic of Indonesia states that the State of Indonesia is a rule of law, which implies that the system of governance of the Republic of Indonesia must be based on the principle of people's sovereignty and the principle of a rule of law.Basically, discretion is inherent in the government in line with the increasing demands for public services that the government must provide for the socio-economic life of citizens of a very dynamic developing state. In essence, the giving of discretion is the granting of authority, and in relation to the granting of that authority in administrative law there is no authority without accountability. This can be interpreted that in the use of discretion there is responsibility.Discretionary actions or legal actions from government positions carried out by office holders or government officials as an organ of government, need to be balanced by institutions or bodies that have a role as a control agency. Thus the legal position of government officials has a high level of prudence, and has compliance based on the concept of public law as representatives of government positions or organs, and their discretionary actions can be accounted for by policy actors.
\end{abstract}

Keywords: Authority, Secretion, Regional Head and Government Administration

DOI: $10.7176 / \mathrm{JLPG} / 103-04$

Publication date: November $30^{\text {th }} 2020$

\section{Introduction}

In accordance with the provisions of Article 1 paragraph (2) of the 1945 Constitution, sovereignty rests in the hands of the people and is exercised according to the 1945 Constitution. Furthermore, according to the provisions of Article 1 paragraph (3) of the 1945 Constitution, the state of Indonesia is a constitutional state. This means that the governing system of the Republic of Indonesia must be based on the principle of people's sovereignty and the principle of a rule of law. The use of state power over society is not without conditions. Society cannot be treated arbitrarily as an object. Decisions and / or actions against the community must be in accordance with the provisions of laws and regulations and the general principles of good governance. Therefore, the system and procedure for implementing government and development tasks must be regulated in a law.

The task of government to realize the goals of the state is formulated in the preamble of the 1945 Constitution, which is the scope of the duties of Government Administration so that regulations are needed that can direct the administration of Government to be more in line with the expectations and needs of the community (citizen friendly), in order to provide a foundation and guidelines for the Agency and / or Government Officials in carrying out government administration tasks.

Provisions for governance are regulated in a law, among others; Law Number 30 of 2014 concerning Government Administration, guarantees basic rights and provides protection to citizens and guarantees the implementation of state duties of a state based on the provisions of Article 27 paragraph (1), Article 28 D paragraph (3), Article $28 \mathrm{~F}$, and Article 28 I paragraph (2) of the Amendment of the 1945 Constitution. Based on these provisions, society is not an object, but a subject who is actively involved in the administration of government.

Law Number 30 of 2014 concerning Government Administration specifically actualizes the constitutional norms of the relationship between the state and citizens. The regulation of Government Administration is an effort to build basic principles, mindset, attitude, behavior, culture and administrative action patterns that are democratic, objective, and professional in order to create justice and legal certainty.

In the administration of government, both at the central and regional levels, the 1945 Constitution contains or outlines the distribution of power both vertically and horizontally. The horizontal separation of powers (sideways) gave birth to state institutions at the central level that had an equal position, namely the legislative, executive and judiciary, which were regulated by a check and balance mechanism. Meanwhile, the vertical distribution of power is known as the territorial distribution of power. This in turn gave rise to the concepts of central government and local government. 1

\footnotetext{
${ }^{1}$ Usman Haryanto, 2017, Sistem Ketatanegaraan di Indonesia, Yogyakarta, Jakal Press, p. 62.
} 
Since independence until now, the distribution of power / authority from the central government to regional governments has always moved at a different balance point. At one time the weight of power rests with the Central Government and on another occasion the heavier weight of power lies with the Regional Government. Likewise the changes, 1 moving very dynamically from one system that is centralized to another system that is decentralized. In line with this, that the principles used in regional autonomy are also constantly shifting according to the configuration of shifting political configurations, starting from the principles of formal autonomy, material autonomy, as broad as possible autonomy, real and accountable autonomy to real, dynamic autonomy. and be responsible, including regulatory products that form the basis of government administration. According to Mahfud MD, this shift gave birth to various forms of legislation regulating the relationship between the central government and local governments. 2

Since the reform era in Indonesia in 1998/1999, various changes have occurred in the structure of the political system and government. The changes that have occurred are seen as a new step for the creation of Indonesia in the future with the basics of democratization in the administration of regional governments.

One aspect of reform that has received attention to date is the issue of regional autonomy policy. Initially, the government began to issue a decentralization policy (political and fiscal) using the legal framework of Law Number 22 Year 1999 concerning Regional Government and Law Number 25 Year 1999 concerning Financial Balance between Central and Regional Government, which was later revised by Law Law Number 32 of 2004 concerning Regional Government and Law Number 33 of 2004 concerning Financial Balance between Central and Regional Government. Furthermore, Law Number 32 of 2004 concerning Regional Government was replaced by Law Number 23 of 2014 concerning Regional Government which was later amended by Law Number 9 of 2015 concerning the Second Amendment to Law Number 23 of 2014 concerning Regional Government. With this legal basis, it brought significant changes to the relationship between the center and the regions.

Changes in local government legislation in Indonesia resulted in the government system moving from a largely centralized government system to one that was decentralized. Furthermore, the concept of a decentralized system is always associated with efficiency and innovation, because through decentralization it will be able to cut several stages of the bureaucracy. Open innovation, because of the power to be able to make the lowest decisions. With the principle of decentralization / freedom to make decisions, there is an opportunity to develop innovation. Some of the advantages of implementing a decentralized system include, reducing the accumulation of central work in the regions, not having to wait for instructions from the center for work to be completed immediately, reducing bureaucracy in a bad sense, reducing arbitrariness from the central government and will improve service quality. ${ }^{3}$

Philosophically, based on the provisions of Article 18 paragraph (7) of the 1945 Constitution of the Republic of Indonesia, the implementation of regional government is directed at accelerating the realization of community welfare through improving services, empowerment and community participation, as well as increasing regional competitiveness by taking into account the principles of democracy., equity, justice, and the uniqueness of a region in the system of the Unitary State of the Republic of Indonesia. The sociological consequences, efficiency and effectiveness of regional government administration need to be improved by paying more attention to aspects of the relationship between the Central Government and regions and between regions, the potential and diversity of regions, as well as the opportunities and challenges of global competition in the unified state administration system. The logical juridical consequence of being a unitary state is that the government of the State of Indonesia was formed as a national government for the first time then the government then formed a region in accordance with the provisions of laws and regulations. Then Article 18 paragraph (2) and paragraph (5) of the 1945 Constitution states that the Regional Government has the authority to regulate and administer Government Affairs by itself according to the Principles of Autonomy and Co-Administration and is granted the widest possible autonomy. ${ }^{4}$

The granting of the widest possible autonomy to the regions shall be implemented based on the principle of a unitary state. In a unitary state the sovereignty only exists in the state government or national government and there is no sovereignty in the Region. Therefore, no matter how wide the autonomy is granted to the Regions, the final responsibility for the administration of the Regional Government will remain in the hands of the Central Government. For this reason, Regional Government in a unitary state is an integral part of the National Government. Policies made and implemented by regions are an integral part of national policies. In terms of the implementation of Regional Government, based on Law Number 23 of 2014 concerning Regional Government Article 17 states that;

Regions have the right to determine Regional policies to carry out Government Affairs which become the

\footnotetext{
${ }^{1}$ J Kaloh, 2012, Mencari Bentuk Otonomi Daerah, Jakarta, Rineka Cipta, p..21.

${ }^{2}$ Mahfud MD, 1999, Hukum dan Pilar-Pilar Demokrasi, Yogyakarta, Gama Media, p. .272

${ }^{3}$ Hendro Kumoro, 2017, Sistem Pemerintahan Daerah di Indonesia, Jakarta, Inter Media, p. 71

${ }^{4}$ Indonesia, Undang-Undang Nomor 23 Tahun 2014 Tentang Pemerintahan Daerah, Penjelasan Undang-Undang Pemerintahan Daerah
} 
authority of the Regions.

(1) In determining regional policies as meant in paragraph (1), it is obligatory to adhere to the norms, standards, procedures and criteria that have been stipulated by the Central Government.

(2) In the event that regional policies made in the framework of administering Government Affairs which become regional authorities do not follow the norms, standards, procedures and criteria as referred to in paragraph (2), the Central Government shall cancel the Regional policies as referred to in paragraph (1).

(3) If within the period of 2 (two) years as referred to in Article 16 paragraph (5) the Central Government has not yet established norms, standards, procedures and criteria, the Regional Government administrators shall carry out Government Affairs which become regional authorities. ${ }^{1}$

Based on the substance of Article 17, juridically and in the context of legitimized authority over regional government policies, the discretionary nature is given to local governments. According to Law of the Republic of Indonesia Number 30 of 2014 concerning Government Administration Article 1 point 9, Discretion is a decision and / or action determined and / or carried out by Government Officials to overcome concrete problems faced in the administration of government in terms of laws and regulations giving choices, not regulating, incomplete or unclear, and / or the stagnation of government. Based on the background described above, the problem is "How is the Discretionary Authority of the Regional Head in the Implementation of Regional Government to Achieve Community Welfare?

\section{Research Methods}

The approach to the problem used in this paper is to use a normative juridical approach, namely literature law research and because this research is conducted by having library materials. In this research, a descriptiveanalytical type of research will be used with the reason that the results obtained from the literature study are then analyzed and discussed using a systematic discussion flow. Thus, the results of the analysis and discussion are then described to make it easier to draw some conclusions and submit suggestions

\section{Results And Discussion}

\section{a. Implementation of Regional Autonomy and Decentralization}

Based on the provisions of Article 1 paragraph (3) of the 1945 Constitution of the Republic of Indonesia that the State of Indonesia is a State of Law, which implies that the governing system of the Republic of Indonesia must be based on the principle of people's sovereignty and the principle of the rule of law. The concept of a rule of law provides guarantees for the administration of government in accordance with the rules of law so that government actions or actions are not arbitrary or misuse the powers that be therein. Meanwhile, the conception of a democratic state provides a limitation and a basis, that the people as subjects of State owners who have sovereignty must have guarantees and broad access to governance. ${ }^{2}$

The impact of the 1998/1999 reform from a political perspective, proves that there has been a paradigm shift from a centralized government to a more decentralized one by giving flexibility to regions to realize regional autonomy more broadly in accordance with the distinctive characteristics of the regions. Changes in the constitutional policy are carried out to create civil society in governmental, community and state life that has good governance values. This is very necessary because of the significantly reduced role of the central government in the regions, especially in carrying out preventive supervision. Therefore the elements of good and correct governance can play an important role in the regions. The implementation of good governance is the main prerequisite for realizing the aspirations of society to achieve the goals and ideals of the nation and state. There is a mechanism to regulate accountability in each government agency and strengthen the role and capacity of the parliament as well as the availability of equal access to public information. ${ }^{3}$

The implementation of regional autonomy and decentralization in the power relationship between the central and regional governments is one way to implement the principles of democracy. This means that the principles of democracy must be implemented through the distribution of power both vertically and horizontally. As mandated also in the 1945 Constitution of the Republic of Indonesia is the welfare of society and fulfilling these obligations responsibly as stipulated in Article 28 A to Article 28 I of the 1945 Constitution of the Republic of Indonesia. To fulfill these obligations One of the government's duties in this case is to provide public services which are basic services for citizens who cannot be left behind.

In administrative law, there are 3 (three) public service approaches, namely, the power approach, the human rights approach, and the functional approach. The power approach is related to the legality / legality of the officials holding power in carrying out their office functions, by examining it from the perspective of authority, procedure and substance. In terms of the power approach, it is based on unwritten administrative law norms or general principles of good governance.

\footnotetext{
${ }^{1}$ Indonesia, Undang-Undang Nomor 23 Tahun 2014 Tentang Pemerintahan Daerah, Artikel 17

2 Aminuddin, 2013, Hukum Tata Pemerintahan, Jakarta, Media Press, p. 54,

${ }^{3}$ Junaidi Malik, 2017, Tranformasi Hukum Ketatanegaraan, Jakarta, Gunung Agung, p. 74
} 
Based on the authority given to government administration, the legal basis for government officials to carry out public legal actions is the authority associated with a position (ambt). Position obtains authority through three sources, namely: attribution, delegation and mandate to give birth to authority (bevoegheid, legal power, competence). ${ }^{1}$ As a state that aims to advance general welfare, the inherent function of advancing public welfare in the welfare state has several consequences for the administration of government, namely that the government must play an active role in interfering in the socio-economic life of society. For this reason, the government delegates responsibility for public service.

Based on the principles of regional government administration, it is directed to accelerate the realization of public welfare through improving services, empowerment and community participation, as well as increasing regional competitiveness by taking into account the principles of democracy, equity, justice and the uniqueness of a region in the system of the Unitary State of the Republic of Indonesia; Efficiency and effectiveness of administering autonomous regional governments and realizing the concept of decentralization, so its implementation needs to pay more attention to aspects of the relationship between the Central Government and regions and between regions, the potential and diversity of regions, as well as opportunities and challenges of global competition in the unified state governance system. .

As for the main matters related to regional autonomy and decentralization, based on the provisions of Law Number 23 of 2014 concerning Regional Government as follows;

a. Absolute Government Affairs, is regulated in Article 10 which reads;

Article 10 Paragraph (1); Absolute government affairs as referred to in Article 9 paragraph (2) include: a. foreign policy; b. defense; c. security; d. yustisi; e. national monetary and fiscal; and f. religion. ${ }^{2}$

Paragraph (2); In carrying out absolute governmental affairs as referred to in paragraph (1), the Central Government: a. carry out yourself; or b. Delegate authority to vertical agencies in the regions or governors as representatives of the Central Government based on the principle of Deconcentration.

b. Concurrent Governmental Affairs, regulated in Article 11 which reads;

Paragraph (1) Concurrent governmental affairs as referred to in Article 9 paragraph (3) which become the regional authorities consist of Compulsory Government Affairs and Elective Government Affairs.

Paragraph (2) Compulsory Government Affairs as referred to in paragraph (1) consist of Government Affairs related to Basic Services and Government Affairs which are not related to Basic Services. Paragraph (3) Compulsory Government Affairs relating to Basic Services as referred to in paragraph (2) are Compulsory Government Affairs which in substance are part of Basic Services.

Article 12 (1) Compulsory Government Affairs relating to Basic Services as referred to in Article 11 paragraph (2) include: a. education; b. health; c. public works and spatial planning; d. public housing and residential areas; e. peace, public order, and protection of the community; and f. social. Paragraph (2) Compulsory Government Affairs that are not related to Basic Services as referred to in Article 11 paragraph (2) include: a. labor; b. empowerment of women and child protection; c. food; d. land; e. living environment; f. population administration and civil registration; g. community and village empowerment; h. Population control and family planning; i. transportation; j. communication and informatics; k. cooperatives, small and medium enterprises; 1. capital investment; m. youth and sports; n. statistics; o. coding; p. culture; q. library; and r. record management. (3) Optional Government Affairs as referred to in Article 11 paragraph (1) include: a. marine and fisheries; b. tourism; c. agriculture; d. forestry; e. energy and Mineral Resources; f. trading; g. industry; and h. transmigration.

Article 13 Paragraph (1) The division of concurrent government affairs between the Central Government and Provincial Regions and Regency / City Regions as referred to in Article 9 paragraph (3) is based on the principles of accountability, efficiency and externalities, as well as national strategic interests. Paragraph (2) Based on the principles referred to in paragraph (1), the criteria for Government Affairs which fall under the authority of the Central Government are: a. Government Affairs which are located across provinces or across countries; b. Governmental Affairs whose users are cross-provincial or cross-country; c. Government Affairs whose benefits or negative impacts are cross-provincial or cross-country, d. Government Affairs which use resources more efficiently when carried out by the Central Government; and / or e. Government Affairs whose role is strategic for the national interest.

Paragraph (3) Based on the principles referred to in paragraph (1), the criteria for Government Affairs which become the authority of a provincial Region are: a. Government Affairs which are located across districts / cities; b. Government Affairs whose users are cross-regency / municipal; c. Government Affairs whose benefits or negative impacts are cross-regency / municipal; and / or d. Government Affairs which use resources more efficiently if carried out by Provincial Regions. Paragraph (4) Based on the principles referred to in paragraph (1), the criteria for Government Affairs which become the authority of a regency / city are: a. Government

\footnotetext{
${ }^{1}$ Ibid. p. 81.

${ }^{2}$ Nawawi Ilham, (2016), Administrasi Pemerintahan, Jakarta; Pena Media, p. 129
} 
Affairs located in a regency / city area; b. Government Affairs whose users are in the Regency / City Region; c. Government Affairs whose benefits or negative impacts are only in the regency / city area; and / or d. Government Affairs which use resources more efficiently when carried out by regencies / cities.

Article 14 Paragraph (1), Implementation of Government Affairs in the forestry, maritime affairs, as well as energy and mineral resources shall be divided between the Central Government and the Provincial Regions. Paragraph (2) Governmental affairs in the forestry sector as referred to in paragraph (1) relating to the management of regency / municipal forest park become the authority of regency / municipality. Paragraph (3) Government affairs in the sector of energy and mineral resources as referred to in paragraph (1) relating to the management of oil and natural gas fall under the authority of the Central Government. Paragraph (4) Government affairs in the sector of energy and mineral resources as referred to in paragraph (1) relating to the direct utilization of geothermal energy in a regency / municipal Region shall become the authority of a regency / municipal Region. Paragraph (5) The producing regency / city which is the producing and not the producing region shall receive the profit sharing from the administration of Government Affairs as referred to in paragraph (1) (6) Determination of producing district / city regions for the calculation of marine production sharing is marine products that are within the boundaries of an area of 4 (four) miles measured from the coastline towards the high seas and / or to archipelagic waters. (7) In the event that the boundaries of the regency / municipality as referred to in paragraph (6) are less than 4 (four) miles, the boundaries of the area are divided equally or measured in accordance with the principle of the center line of the adjacent Area.

Article 15 Paragraph (1), The division of concurrent government affairs between the Central and Provincial Governments as well as district / municipal regions is listed in the Appendix which is an integral part of this Law. Paragraph (2) Concurrent governmental affairs that are not listed in the Attachment to this Law shall become the authority of each level or structure of government which determines using the principles and criteria for the division of concurrent government affairs as referred to in Article 13. Paragraph (3) Concurrent government affairs as referred to in paragraph (2) stipulated by a presidential regulation. Paragraph (4) Amendments to the division of concurrent government affairs between the Central and Provincial Governments and Regency / City Regions as referred to in paragraph (1) which do not result in the transfer of concurrent government affairs at other levels or structures of government are stipulated by a government regulation. Paragraph (5) Amendments as referred to in paragraph (4) can be carried out as long as they do not conflict with the principles and criteria for the division of concurrent government affairs as referred to in Article 13.

Article 16 Paragraph (1) The central government in carrying out concurrent government affairs as referred to in Article 9 paragraph (3) has the authority to: a. stipulating norms, standards, procedures and criteria in the framework of implementing Government Affairs; and b. carry out guidance and supervision of the administration of Government Affairs which become the authority of the Region. Paragraph (2) Norms, standards, procedures, and criteria as referred to in paragraph (1) letter a are in the form of statutory provisions stipulated by the Central Government as a guideline in carrying out concurrent government affairs which fall under the authority of the Central Government and which become the authorities. Area. Paragraph (3) The authority of the central government as meant in paragraph (1) is exercised by ministries and non-ministerial government agencies. Paragraph (4) The exercise of authority exercised by non-ministerial government agencies as referred to in paragraph (3) must be coordinated with the relevant ministries. Paragraph (5) The stipulation of norms, standards, procedures and criteria as referred to in paragraph (1) letter a shall be carried out no later than 2 (two) years from the promulgation of government regulations concerning the implementation of concurrent government affairs.

Article 18 Paragraph (1) Regional Government Administrators prioritize the implementation of Compulsory Government Affairs related to Basic Services as referred to in Article 11 paragraph (3). Paragraph (2) Implementation of Basic Services in Compulsory Government Affairs relating to Basic Services as referred to in section (1) shall be guided by the minimum service standards set by the Central Government. Paragraph (3) Further provisions regarding minimum service standards are regulated by government regulations.

\section{b. Discretion of Regional Heads in Regional Government Administration}

Thomas J. Aaron defines discretion as a power or authority exercised based on law based on considerations and beliefs and emphasizes moral considerations more than legal considerations (discretion is power authority conferred by law to action on the basic of judgment of conscience, and its use is more than idea of morals than law). ${ }^{1}$

According to Soerjono Soekanto, ${ }^{2}$ discretion regarding decision-making is not strictly bound by law, where personal judgment also plays a role. According to Lawrence.M. Friedman, Discreationary Power is divided into 2 (two), namely Formal Discretion and Real Discretion. Formal discretion exists in a legal system, while Real Discretion is outside the legal system. Formal discretion tends to be somewhat controversial but is a very

\footnotetext{
${ }^{1}$ M. Faal, 2001, Penyaringan Perkara Pidana Pleh Polisi (Diskresi Kepolisian), Jakarta, Pradnya Paramita, p. 16.

${ }^{2}$ Soerjono Soekanto, 2002, Faktor-Faktor yang Mempengaruhi Penegakan Hukum, Jakarta, Raja Grafindo Persada, p. 15
} 
interesting and important fact. ${ }^{1}$ According to Indriyanto Senoadji, discretionary power or Freies Ermessen is a policy divided into two definitions, namely bound policy and active policy.

From an academic juridical perspective, a policy (beleid), either as a bound (discretionary) policy or an active (discretionary) policy, is not the area of assessment of criminal law. Discretion can be exercised by public officials and in practice if it is in the form of a government decision prioritizing the achievement of its goals (doelmatigheid) rather than the legality of the applicable law (rechtsmatigheid). Discretion has three conditions, namely (1) for the sake of public interest; (2) still within the scope of their authority; and (3) not violating the general principles of good governance.

Discretion as governmental authority is a free authority possessed by government officials as well as as an opponent of bound authority. The nature and legal character of this government action requires that government power is not just implementing laws, but must prioritize the setting of goals and policies. The government's actions that prioritize "doelstelling" and "beleid" are active powers. According to Philipus M.Hadjon, ${ }^{2}$ this active nature in the concept of Administrative Law is intrinsically the main elements of "sturen" (besturen). In the concept of bestuur (besturen), government power in the exercise of governmental authority is not merely a bound authority as stated in the rule of law, but also as a free or discretionary authority.

In the Black Law Dictionary, the term "discretion" means "A public official's power or right to act in certain circumstances according to personal judgment and conscience". ${ }^{3}$ Discretion in this approach is defined as the authority of a judge, public official or private party (acting on the basis of the authority given by an agreement) to make decisions in various areas based on their own opinion by referring to normative legal rules. The concept of discretion in the discretionary power approach is the authority possessed by both judges, public officials and private parties. In this case discretion is in the realm of public law and civil aw. Philipus M. Hadjon's discretionary power concept distinguishes 2 (two) kinds of governmental freedom, namely beleidvrijheid (freedom of wisdom) and beoordelijngvrijheid (freedom of judgment). ${ }^{4}$

Discretion can mean freedom of wisdom as discretion in the narrow sense that gives authority to government officials to decide independently, while in the sense of freedom of judgment as discretion in an unreasonable sense, it gives authority to interpret the disguised norms. As opposed to bound authority, discretion in free authority is an option to carry out government actions related to the formulation of norms containing factual conditions such as emergencies, disasters and others. ${ }^{5}$

Against free power, it is not intended as an unlimited power. Free power remains a power subject to law, at least to unwritten law in the form of legal principles. In the Indonesian administrative law literature these principles were originally popular as "general principles of good governance" so that until now the word "behoorlijk" was interpreted as "good". ${ }^{6}$

Several formulations are often found in various laws and regulations or various government decisions: ${ }^{7}$

1. Matters that have not been regulated in this decision will be determined later. It appears that it is unclear what has not been regulated, and that "will be determined later".

2. For public order, the Governor may prohibit the use of foreign languages in billboards.

3. In the event that the license holder does not fulfill the obligations stated in Article II, the license is revoked.

4. The Governor of the Regional Head issued regulations related to the Covid 19 outbreak, and others.

In running the government, the Government has been equipped with powers both attributive and delegative in nature. With the development of society, there are often certain circumstances that are urgent in nature that make the Officials / Bodies of the 'government administration unable to use their powers, especially those which are bound to carry out legal actions and factual actions normally.

The implication of public services is that the government also cannot refuse to take action in executing its government functions on the grounds that there are no rules regulating it. This condition makes the government use the principle of freies ermessen or discretion.Based on the provisions of Law Number 30 of 2014 concerning Government Administration, Chapter VI has regulated the general provisions of discretion, scope, requirements, procedures for use up to the consequences of discretionary law. Apart from being a foundation and guidelines for government agencies and / or officials in carrying out governmental administration tasks, given the wide scope of the duties of Government Administration, the presence of Law No. 30 of 2014 concerning Government Administration is also expected to be able to guarantee protection to every community.

Important urgent issues, at least contain the following elements:

\footnotetext{
${ }^{1}$ Lawrence M.Friedman, 1975, The Legal A Social Science Perspective, Russel Sage Foundation, New York, p. 45. In the book

${ }^{2}$ Indriyanto Senoadji, 2010, Korupsi Kriminalisasi Kebijakan, Bandung, Ganesha Press, p. 212.

${ }^{3}$ Philipus M.Hadjon, 2007, Discretionary Power dan Asas-Asas Umum Pemerintahan Yang Baik (AAUPB), Dharmawangsa Press, p. 23.

${ }^{4}$ Philipus M.Hadjon, Loc Cit, P. 31

${ }^{5}$ Henry Campbell Black, 1990, Black's Law Dictionary, West Publishing, p. 479.

${ }^{6}$ Kuntjoro Purbopranoto, 2014, Beberapa Catatan Hukum Tata Pemerintahan dan Peradilan Administrasi Negara, Jakarta, Intermasa, P. 29

${ }^{7}$ Philipus M.Hadjon, Loc Cit, P. 48
} 
a. Problems that arise must be related to the public interest, namely the interests of the nation and the state, the interests of the wider community, the interests of the people at large / together, and the interests of development.

b. The emergence of these problems suddenly, is outside the predetermined plan.

c. To resolve these problems, the laws and regulations have not yet regulated it or only regulate it in general, so that the State administration has the freedom to resolve it on its own initiative.

d. The procedure cannot be completed according to normal administration, or if it is completed according to normal administrative procedure it is less efficient and effective. ${ }^{1}$

The existence of discretionary powers means that some of the powers held by the legislative bodies are transferred to the hands of the government / state administration as the executive body. So the supremacy of the legislative body is replaced by the supremacy of the executive branch, ${ }^{2}$ because the state administration resolves problems without having to wait for changes to laws from the legislative field. This is because in principle government administrative bodies / officials may not refuse to provide services to the community on the grounds that the law does not exist or the law exists but is unclear, as long as this is within their authority.

This is because government administrative officials / agencies can take legal and or factual actions. In their position as a legal subject, the Government Administration Officer / Agency can take legal actions that can give rise to legal rights and obligations. As a supporter of rights and obligations, every act or act of government law has consequences or consequences of the actions or deeds it does.

In carrying out legal actions and or factual actions, Government Administrative Officials or Bodies have government instruments. The government instruments referred to in this case are the tools or facilities used by the government or state administration in carrying out its duties. In carrying out government duties, the government carries out various legal actions by using means or instruments such as writing instruments, means of transportation, office buildings and others, which are grouped into the public domain or belonging to the public. In addition, the government also uses various juridical instruments in carrying out activities, regulating the running of government and social affairs, such as laws and regulations, decrees, policy regulations, licensing and so on. ${ }^{3}$

Legal products from government administrative bodies / officials in the form of documents containing concrete, individual and final determination materials in administrative law are called decisions (beschikking), while documents that contain general regulatory material are called regulations (regeling). As for licensing, it is an exemption from the prohibitions contained in a regulation. Government instruments are set out in the form of regulations regarding permits for certain matters, while the basis for implementation / operations for the community or government administrative bodies / officials is in the form of government administrative decisions regarding permits for certain matters.

Meanwhile, the policy regulation is a legal product born from the authority to regulate the public interest independently on the basis of the freies ermessen principle which in practice is often found to be stated in the form of Presidential Decrees and Ministerial Decrees. As a result, a lot of Presidential Decrees have been enacted, including with regard to material provisions which should have been set forth in the form of a Law, which the President has personally stipulated without involving the House of Representatives.

In carrying out government functions, government actions must be based on the authority owned and not on power. In Indonesia, the regulation of the authority for attribution and delegation can be found in the 1945 Constitution and laws. However, the development of needs is so fast with more diverse government affairs, that not all functions can be carried out solely based on the authority of attribution, delegation and mandate.

Facing this situation, the government must be active in overcoming this. This is in accordance with one of the characters in government according to law. This reality then raises a discretion whose goal is to resolve government affairs on the basis of the absence of legal regulations or unclear laws, urgent circumstances and so on. But of course the use of discretion must also be based on the authority that gives the government apparatus freedom of action to use discretion and not government power.

Discretion in Law Number 30 of 2014 concerning Government Administration is regulated in articles 22 to 32, namely regarding the General Section, the Scope of Discretion, Requirements, Procedures for the Use of Discretion, and the Legal Consequences for the Use of Discretion, although in this law there is no explanation regarding the concept of discretion explicitly only in article 23 point (a) mentions the scope of discretion is a choice of decisions or actions.

The use of discretion must be based on the authority possessed by government officials, as regulated in article 22 paragraph 1 of Law No.13 / 2014 concerning Government Administration which states that: Discretion can only be exercised by authorized Government Officials. Because the essence of this governmental authority is

\footnotetext{
Ibid, P. 17

2 Sundari Soetami, 2016, Hukum Administrasi Negara, Jakarta, Citra Media, P. 53

${ }^{3}$ Diana Halim, 2014, Hukum Administrasi Negara, Bogor, Ghalia Indonesia, p. 149.
} 
also a function of people's control over the government in acting. ${ }^{1}$

Freies Ermessen is a logical consequence of the conception of the welfare state. The freies ermessen elements in a constitutional state are as follows:

a. Intended to perform public service tasks;

b. $\quad \mathrm{s}$ an active act of the State administration;

c. This attitude of action is made possible by law;

d. The attitude of the action was taken on his own initiative;

e. This attitude of action is intended to resolve important problems that arise suddenly;

f. The attitude of such actions can be accounted for both morally to God Almighty and legally. ${ }^{2}$

In general, government actions based on Ermessen or discretion, if set forth in writing, will produce policy regulations. In relation to statutory regulations, policy regulations are state administrative law instruments aimed at dynamizing the validity of statutory regulations. ${ }^{3}$ In practice, the government often uses policy regulations as the basis for implementing a policy.

Although the granting of discretion or free authority (discretionary power) to the government is a logical consequence in the conception of the welfare state, the granting of discretionary powers is not without problems. Because the existence of this free authority means that there is an opportunity for abuse of authority (detournement de pouvoir) or arbitrary action (willekeur) that can harm citizens. In line with the breadth of government tasks, especially in providing public services to citizens, it is inevitable that giving discretion to the government seems to have become imperative.

However, giving discretion to the government is not without problems. Discretion allows and even gives officials the opportunity to transcend borders, offensive discrimination, subordinates the public interest to one's private interests, conceals bureaucratic reasons and goals, and abuses the population in many large and small ways . Discretion is the most difficult aspect of bureaucratic power to monitor in any legal regime.

In the practice of governance in Indonesia, both at the central and regional levels when carrying out their duties and authorities, public law norms or administrative law norms are always applied to them, but sometimes many things are related to policies taken by officials which when conflicts occur, always deemed to be detrimental to State finances and have an impact on the interests of society, what is applied is the norm of criminal law.

There is a very wide range of powers in the use of discretion, and for that there is a need for responsibility. Philipus M. Hadjon stated to make it easier to provide an understanding of free power or discretionary power by looking at its scope. Free or discretionary powers include:

1. the authority to decide by yourself

2. authority to interpret the norms disguised (vage normen). ${ }^{4}$

Free power here does not mean unlimited power, but still within the corridor of law, at least to written law or legal principles. Public legal entities in the form of the state, government, ${ }^{5}$ departments, local governments, institutions in order to carry out their duties they need authority. The granting of authority to these public legal entities can be seen in the constitution of each country.

The matter of authority cannot be separated from the Constitutional Law and Administrative Law because these two types of law regulate authority, especially the distribution of power within the State. Administrative law or governance law contains norms of governmental law. These governmental legal norms are the parameters used in the exercise of authority by government agencies. The parameters used in the use of authority are legal compliance or legal non-compliance, so that if there is an improper illegal use of the authority, the authorized government agency must be held accountable.

The point is that, administrative law is essentially related to public authority regarding the discretion exercised by regional government officials and methods of testing their authority, the applicable law regarding control of this authority must be accountable for the applicable legal provisions.

\section{Responsibilities of Government Officials Against the Use of Discretionary Authority}

Based on a study of constitutional law and state administrative law, the terms "power" and "authority" are closely related to the implementation of government functions. The word "power" comes from the word "power" which means the ability or ability (to do something); power. Meanwhile "authority" is (1) the right and power to act or do something; (2) the power to make decisions, rule and delegate responsibilities to others. ${ }^{6}$

\footnotetext{
Diana Halim, 2014, Hukum Administrasi Negara, Bogor, Ghalia Indonesia, p. 149.

2 Sjachran Basah, 2015, Eksistensi dan Tolok Ukur Peradilan Administrasi di Indonesia, Bandung, Alumni, p. 61.

${ }^{3}$ Laica Marzuki, 2016, Peraturan Kebijaksanaan,Hakikat serta Fungsinya selaku Selaku Sarana Hukum Pemerintahan, Yogyakarta, Jakal Press, p. 31.

${ }^{4}$ Ibid, hal.146.

${ }^{5}$ Jimly Asshiddiqie, 2004, Format Kelembagaan Negara dan Pergeseran Kekuasaan Dalam UUD 1945, FH UII Press, Jogjakarta, p. 25.

${ }^{6}$ Irfan Fachruddin, 2004, Pengawasan Peradilan Administrasi terhadap Tindakan Pemerintah, Bandung, Alumni, p. 38.

${ }^{6}$ Sumarwoto, 2011, Hukum Tata Pemerintahan, Jakarta, Intermasa, p. 138.
} 
Authority as power to act, power to make decisions, to rule and delegate responsibility to other parties. The ability to take certain legal actions, namely actions that are intended to cause legal consequences, and include the arising and disappearance of certain legal consequences. Based on the analogy, authority can be interpreted as legal power, because authority as a concept of public law always has to have clear arrangements both in constitutional law and in administrative law, thus through this regulation gives power or ability to state administrative officials to take action. which has consequences in the field of public law. Such a strong relationship between authority and power, so that the two terms are often used in the same sense.

Every state and government administration must have legitimacy, that is, the authority granted by law. the ability to perform certain legal actions. An attribution refers to the original authority based on the provisions of constitutional law. Attribution is the authority to make decisions (besluit) which originate directly from the law in a material sense. Another formula says that attribution is the formation of certain powers and giving them to certain organs. Those that can establish authority are authorized organs based on statutory regulations. ${ }^{1}$

Attribution occurs when a new government authority is granted by a provision in the legislation. Furthermore, the delegation confirmed a delegation of authority to other government bodies. That is, those who give / delegate authority are called delegates and those who receive are called delegates. So a delegation is always preceded by an attribution of authority. If the concept of delegation is like that, then there is no general delegation and there can be no delegation from superiors to subordinates. Attribution is concerned with the transfer of new authority, while delegation is concerned with the delegation of existing powers (by organs that have acquired attributive authority to other organs); so logically delegation is always preceded by attribution. The word delegate (Delegatie) means the transfer of authority from a higher official to a lower one. Such surrender is deemed unjustifiable other than with or based on legal force. With delegation, there is a transfer of authority from one government agency or official to another government agency or official.

One of the principles of rule of law is that every action of government organs must be based on authority. In general, every action of government organs is the use of authority, because it is always related to accountability. In the modern rule of law concept, the government has the obligation to provide optimal services to the community, where in the framework of this service the government organs are equipped with a number of powers, including discretionary authority. Basically, discretion is inherent in the government in line with the increasing demands for public services that the government must provide for the socio-economic life of citizens of a very dynamic developing state. In essence, the giving of discretion is the granting of authority, and in relation to the granting of that authority in administrative law there is no authority without accountability. This can be interpreted that in the use of discretion there is responsibility.

Discretion in Law Number 30 of 2014 is regulated in articles 22 to article 32, namely regarding the general section, the scope of discretion, requirements, procedures for using discretion, and the legal consequences of using discretion. This law does not explicitly explain the concept of discretion, but in article 23 point (a) it states that the scope of discretion is a choice of decisions or actions. There are several things in the articles that regulate this discretion which in the opinion of the writer it is necessary to understand properly its purpose so that it is not misinterpreted in its implementation. For example, in articl 23 letter (c): the discretion of government officials includes making decisions and / or actions because the statutory regulations are incomplete or unclear.

The meaning of decision making, because the laws and regulations are incomplete or unclear, must be interpreted with caution. The incomplete definition is closely related to the formation of incomplete norms. Meanwhile, the unclear definition relates to the content of rules or norms that have vague meanings which are often called vage norms. Meanwhile, the obscure meaning, according to the author, means a concept that cannot be defined, for example the formulation of the concept of public interest, the concept of factual conditions, in certain circumstances, and in compelling urgency. Article 24 in particular letters (c) and (d) stipulates that government officials who use discretion must meet the requirements, namely in accordance with the AUPB and based on objective reasons. As has been explained that the government is a legal subject that can take legal actions or actions that give birth to legal consequences, both positive and negative legal consequences. Usually positive legal consequences are not related to responsibility, while negative legal consequences always have to do with responsibility because it raises demands from those who feel they have been aggrieved. In the administration of government, this responsibility is attached to the position to which juridical authority is attached. In the perspective of public law, this authority creates responsibility, including discretionary policies.

\section{CLOSING}

In essence, that government organ is a part or tool of a legal entity according to the provisions of private law. Thus, that a position does not have assets, but as an organ that is part of a government legal entity, in carrying out its functions and duties, its position can use the assets of its legal entity.

\footnotetext{
${ }^{1}$ Sumarwoto, 2011, Hukum Tata Pemerintahan, Jakarta, Intermasa, p. 138.
} 
In practice, although a government position is attached to it the authority to carry out an act or legal act of government which is manifested in a discretionary form, it is impossible for the government office to act or act independently. Government positions can only take legal actions or actions, if through an intermediary or representative, namely, a holder or holder of an office or better known as an official who acts for and on behalf of the interests of the interests of the government office. Government positions can run because someone represents them to carry out an act or legal act of government.

In his position as holder or holder of an office at the same time exercising discretionary authority, rights and obligations attached to the position, so that officials in the sense of administrative law do not have the authority, rights and obligations but only exercise or administer the authority, rights and obligations that exist or are attached to the position. the. The discretionary legal actions of officials representing the interests of the office must always be considered legitimate unless it can be proven otherwise that the actions or actions of the holder or office holder are not valid. This is in accordance with the legal principle in administrative law which stipulates that government legal actions or actions must always be considered valid until they can be proven otherwise or until there is a cancellation for that

Thus, discretionary actions or legal actions from government positions carried out by office holders or government officials as an organ of government need to be balanced by institutions or bodies that have a role as a control agency. Thus the legal position of government officials has a high level of prudence, and has compliance based on the concept of public law as representatives of government positions or organs, and their discretionary actions can be accounted for by policy actors.

\section{BIBLIOGRAPHY}

Books

Aminuddin, 2013, Hukum Tata Pemerintahan, Media Press, Jakarta.

Baharudin Achmad, 2013, Hukum Pembangunan, Media Press, Jakarta.

Diana Halim, 2014, Hukum Administrasi Negara, Ghalia Indonesia, Bogor.

Donald Morton, 1996, The Politics of Queer Theory in The Post Modern Moment, New York, McGraw-Hill

Harun Kamil, 2012, Hukum, Demokrasi \& Pembangunan Ekonomi, Gramedia, Jakarta.

Hendro Kumoro, 2017, Sistem Pemerintahan Daerah di Indonesia, Inter Media, Jakarta.

Henry Campbell Black, 1990, Black's Law Dictionary, West Publishing.

Indriyanto Senoadji, 2010, Korupsi Kriminalisasi Kebijakan, Ganesha Press, Bandung.

Irfan Fachruddin, 2004, Pengawasan Peradilan Administrasi terhadap Tindakan Pemerintah, Alumni, Bandung. J Kaloh, 2012, Mencari Bentuk Otonomi Daerah, Rineka Cipta, Jakarta.

Jimly Asshiddiqie, 2004, Format Kelembagaan Negara dan Pergeseran Kekuasaan Dalam UUD 1945, FH UII Press, Jogjakarta.

Jimly Asshiddiqie, 2004, Gagasan Kedaulatan Rakyat Dalam Konstitusi Dan Pelaksanaannya di Indonesia, Ichtiar Baru, Jakarta.

Junaidi Malik, 2017, Tranformasi Hukum Ketatanegaraan, Gunung Agung, Jakarta.

Kuntjoro Purbopranoto, 2014, Beberapa Catatan Hukum Tata Pemerintahan dan Peradilan Administrasi Negara, Intermasa, Jakarta.

Laica Marzuki, 2016, Peraturan Kebijaksanaan,Hakikat serta Fungsinya selaku Selaku Sarana Hukum Pemerintahan, Jakal Press, Yogyakarta.

M. Faal, 2001, Penyaringan Perkara Pidana Pleh Polisi (Diskresi Kepolisian), Pradnya Paramita, Jakarta.

Mahfud MD, 1999, Hukum dan Pilar-Pilar Demokrasi, Gama Media, Yogyakarta.

Nawawi Ilham, 2016, Administrasi Pemerintahan, Pena Media, Jakarta.

Philipus M. Hadjon, 1997, Tentang Wewenang, Yuridika, No. 5\&6 Tahun XII.

Philipus M.Hadjon, 2007, Discretionary Power dan Asas-Asas Umum Pemerintahan Yang Baik (AAUPB), Dharmawangsa Press

Ridwan HR, 2012, Hukum Administrasi Negara, UII Press, Yogyakarta.

Sjachran Basah, 2015, Eksistensi dan Tolok Ukur Peradilan Administrasi di Indonesia, Alumni, Bandung.

Soerjono Soekanto, 2002, Faktor-Faktor yang Mempengaruhi Penegakan Hukum, Jakarta; Raja Grafindo Persada

Sumarwoto, 2011, Hukum Tata Pemerintahan, Intermasa, Jakarta.

Sundari Soetami, 2016, Hukum Administrasi Negara, Citra Media, Jakarta.

Usman Haryanto, 2017, Sistem Ketatanegaraan di Indonesia, Jakal Press, Yogyakarta.

Laws and regulations

Indonesia, Undang-Undang Dasar Negara Republik Indonesia Tahun 1945

--------, Undang-Undang Nomor 23 Tahun 2014 Tentang Pemerintahan Daerah 